\title{
Successful treatment of pneumonia-induced severe ARDS complicated with DIC in two infants using recombinant human thrombomodulin
}

\author{
Phan Huu Phuc ${ }^{1}$, Ngo Tien Dong ${ }^{1}$, Ta Anh Tuan ${ }^{1}$, Shoji Kawachi ${ }^{2,3,4}$, Noriko Nakajima ${ }^{3}$, Naoyuki Hirata ${ }^{5}$, Akira Ainai ${ }^{3}$, Phung Thi Bich \\ Thuy $^{1}$, Tran Minh Dien ${ }^{1}$ and Le Thanh $\mathrm{Hai}^{1}$ \\ ${ }^{1}$ National Children's Hospital, Hanoi, Vietnam \\ ${ }^{2}$ National Center for Global Health and Medicine, Tokyo, Japan \\ ${ }^{3}$ National Institute of Infectious Diseases, Tokyo, Japan \\ ${ }^{4}$ Teikyo University, Tokyo, Japan \\ ${ }^{5}$ Sapporo Medical University School of Medicine, Sapporo, Japan
}

\begin{abstract}
Severe acute respiratory distress syndrome (ARDS) complicated with disseminated intravascular coagulopathy (DIC) is a life-threatening disease in childhood for which there is few confirmed therapeutic strategies. Recombinant human soluble thrombomodulin (rhTM) has been widely used for the treatment of DIC as an anticoagulant agent. In addition to anti-DIC effects, recent evidences demonstrated that rhTM could improve ARDS in adult patients via anti-inflammatory effects. On the other hand, the safety and efficacy of rhTM on pediatric ARDS with or without DIC are unclear. In this preliminary study, we administered rhTM for 6 days to two infants with pneumonia-induced severe ARDS ( $\mathrm{PaO} 2 / \mathrm{FiO} 2$ ratio $\leq 100 \mathrm{mmHg})$ with DIC, and investigated clinical course and changes in biochemical markers. After administration of rhTM, clinical symptoms and laboratory data improved in both infants and there was no adverse effect of rhTM. The infants were successfully treated and discharged without any complications.
\end{abstract}

\section{Introduction}

Pneumonia is a leading infectious cause of death in childhood worldwide and $15 \%$ of all deaths in children under five years old [1]. Pneumonia can cause acute respiratory distress syndrome (ARDS) [2,3] and severe ARDS occasionally can induce disseminated intravascular coagulopathy (DIC). Severe ARDS complicated with DIC is one of the lethal conditions of the disease in intensive care unit and the effective treatments remains to be determined [4,5].

Recombinant human soluble thrombomodulin (rhTM), which was primarily developed for the treatment of DIC in adults [6], is now widely administered for treating pediatric patients with DIC $[7,8]$. While previous evidences have shown that the safety and efficacy of rhTM for DIC, recent studies in adults have implicated the efficacy of rhTM on ARDS via anti-inflammatory effects $[9,10]$. On the other hand, there have been few reports investigating the safety and efficacy of rhTM on pneumonia-induced ARDS with or without DIC in pediatric patients. In this preliminary study, we administered rhTM for treatment of pneumonia-induced severe ARDS complicated with DIC in pediatric patients and investigated the safety and efficacy of rhTM.

\section{Case 1}

A 8-week-old Vietnamese infant girl, without a particular family history and a past medical history, was referred to a local hospital with 2 days history of cough, wheeze and mild fever. She was diagnosed as pneumonia and was medicated azithromycin on the day 3rd (the day of onset of the illness defines the day 1st). Over the next 48 hours, she was getting worse with dyspnea and high fever. She was sent to our hospital on the day 6th. Physical examination on admission showed an infant with weight of $5.7 \mathrm{~kg}$; length of $53 \mathrm{~cm}$; body temperature of $38.0^{\circ} \mathrm{C}$; heart rate (HR) of 150 beats/min; and oxygen saturation level $\left(\mathrm{SpO}_{2}\right)$ of $60 \%$ in room air. At the night, she was tracheal intubated and was transferred to pediatric intensive care unit (PICU) on the day 7 th, her blood pressure had dropped to $65 / 35 \mathrm{mmHg}$ with HR of 154 beats/min. The first arterial blood gas analysis in PICU showed $\mathrm{pH}$, 7.37; partial pressure of oxygen $\left(\mathrm{PaO}_{2}\right) 36 \mathrm{mmHg}$; and partial pressure of carbon dioxide $\left(\mathrm{PaCO}_{2}\right), 61 \mathrm{mmHg}$; and bicarbonate $\left(\mathrm{HCO}_{3}^{-}\right), 35 \mathrm{mmol} / \mathrm{L}$, under the mechanical ventilation with $100 \%$ oxygen administration. The $\mathrm{PaO}_{2}$ to the fraction of inspired oxygen $\left(\mathrm{FiO}_{2}\right)$ ratio (P/F ratio) was consequently $36 \mathrm{mmHg}$. Chest $\mathrm{X}$-ray showed bilateral infiltration, with normal heart size (Figure 1). She was diagnosed as severe ARDS developed from pneumonia [11,12]. The Pediatric Risk of Mortality (PRISM) III score was assessed using parameters obtained during the first 12 hours of stay in the PICU and her PRISM III score was 10 [13]. Laboratory findings were as follows, white blood cell (WBC) count

Correspondence to: Naoyuki Hirata, M.D., Ph. D, Department of Anesthesiology, Sapporo Medical University School of Medicine, South-1 West-16, Chuo-ku, Sapporo, Hokkaido, 060-8543, Japan, Tel: +81-11-688-9663; Fax: +81-11-6319683; E-mail: naohirata@mac.com

Key words: acute respiratory distress syndrome, disseminated intravascular coagulation, recombinant human thrombomodulin

Received: May 05, 2017; Accepted: May 27, 2017; Published: May 30, 2017 
28,000 cells $/ \mu$ l; red blood cell $(\mathrm{RBC})$ count $297 \times 10^{4}$ cells $/ \mu \mathrm{l} ;$ platelet (PLT) count $271 \times 10^{3}$ cells $/ \mu$; aspartate aminotransferase (AST) 875 $\mathrm{U} / \mathrm{L}$; alanine aminotransferase (ALT) $325 \mathrm{U} / \mathrm{L}$; blood urea nitrogen (BUN) $14.1 \mathrm{mg} / \mathrm{dL}$; creatinine $24 \mu \mathrm{mol} / \mathrm{L}$; CRP $18.1 \mathrm{mg} / \mathrm{dL}$; fibrinogen $4.71 \mathrm{~g} / \mathrm{L}$; and prothrombin time (PT) 16.1 seconds. No bacteria and fungi were detected in blood neither by culture nor by LightCycler SeptiFast Test (Roche Diagnostics GmbH, Manheim, Germany) which detected and differentiated up to 25 pathogenic microbial DNAs in blood samples using a multiplex polymerase chain reaction (PCR) system [14]. The genomes of respiratory syncytial virus (RSV) and cytomegalovirus (CMV) were detected in tracheal lavage fluid (TLF) by real time PCR assay. CMV-DNAs were detected both in TLF and blood and the copy numbers were 1000 copies $/ \mathrm{ml}$ in either sample. She was treated as severe ARDS/sepsis developed from RSV pneumonia.

To correct an insufficient circulation, dopamine hydrochloride was administrated and $1 \mathrm{~g} / \mathrm{kg}$ of immune globulin was given intravenously for 10 hours for severe sepsis on the day 7 th. As lung protective therapy, pressure controlled volume limited mechanical ventilation had begun according to a protocol, with $12 \mathrm{cmH}_{2} \mathrm{O}$ PEEP and $5-8 \mathrm{ml} /$

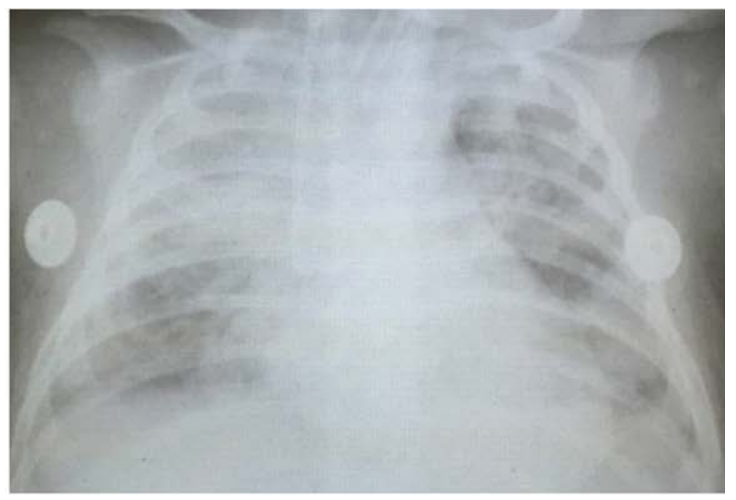

Figure 1. Chest X-ray on admission to PICU in Case 1. $\mathrm{kg}$ tidal volume [15]. PEEP and $\mathrm{FiO}_{2}$ were reducing gradually depends on the $\mathrm{P} / \mathrm{F}$ ratio. For prevention of secondary bacterial infection, broad spectrum antibiotics, $60 \mathrm{mg} / \mathrm{kg} /$ day of imipenem/cilastatin (IPM/CS) and $20 \mathrm{mg} / \mathrm{kg} /$ day of levofloxacin (LVEX) were started from the day 9 th. On the day 9 th, International Society on Thrombosis and Haemostasis (ISTH) DIC score increased to 5 (PLT 55,000/ $\mu$; fibrinogen $4.83 \mathrm{~g} / \mathrm{L}$; D-dimer $1014 \mathrm{ng} / \mathrm{mL}$; and PT 19.7 seconds), presenting a complication of DIC and the DIC score continued to increase for next 2 days [16]. Therefore, for the treatment of DIC, $380 \mathrm{U} / \mathrm{kg}$ of recombinant human soluble therombomodulin (rhTM) in $100 \mathrm{ml}$ normal saline was administered as intravenous drip infusion for more than 30 minutes for 6 days from the day 11th. All necessary treatment that PICU doctors did was acceptable except administration of contraindication for co-administration of thrombolytic agents or tissue plasminogen activators or platelet aggregation inhibitors with rhTM. Hepatorenal function was almost normal throughout the rhTM administration. The DIC score and the $\mathrm{P} / \mathrm{F}$ ratio had been improving gradually, and she was extubated on the day 15 th.

On the same day, she had high fever $\left(38.8^{\circ} \mathrm{C}\right)$. The TLF culture showed Acinetobacter infection and the CMV copy numbers increased to $2.3 \times 10^{5}$ copies $/ \mathrm{ml}$ in blood, suggesting a complication of $\mathrm{CMV}$ disease. Colistin (CL), Amicacin (AMK) and ganciclovir (GCV) were started from the day 16th. The fever went down and she moved from PICU to respiratory department on the day $17 \mathrm{th}$. The clinical course in PICU was shown in Figure 2 and Table 1. She was successfully treated of severe ARDS/sepsis with DIC and discharged from hospital on the day 28 th.

\section{Case 2}

A 3-month-old Vietnamese infant boy went to a private clinic with 2 days of nasal congestion, cough, and mild fever. Though he had started antibiotics on the day $3 \mathrm{rd}$, he was getting worse with high fever, wheeze and dyspnea during the next 4 days. After he went to a local hospital

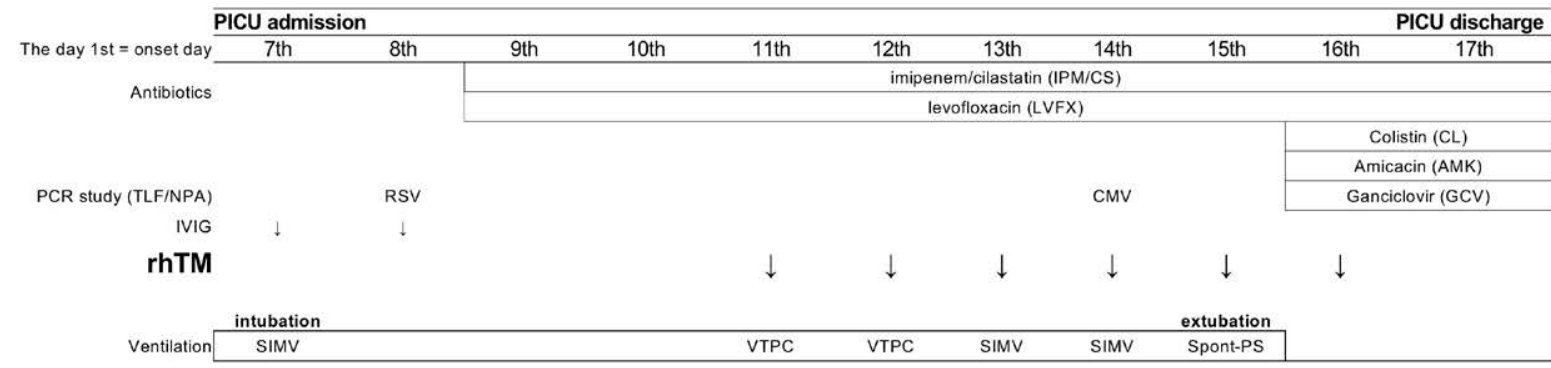

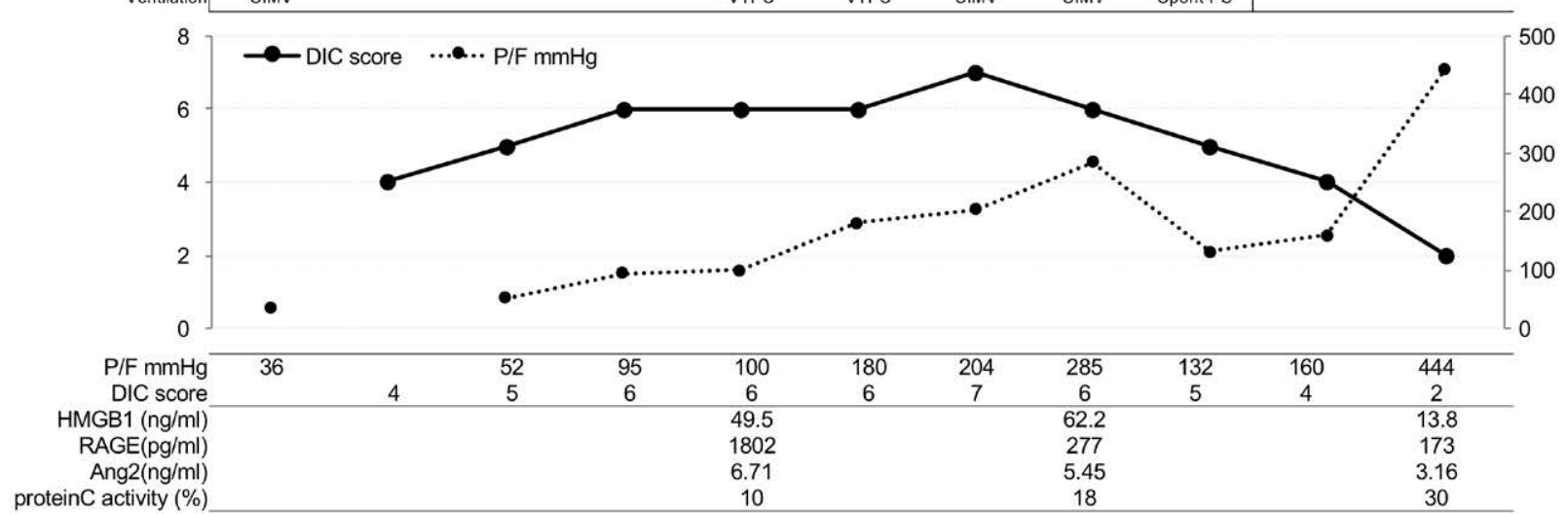

Figure 2. Clinical course in Case 1. RSV; respiratory syncytial virus, CMV; cytomegalovirus, TLF/NPA; tracheal lavage fluid and/or nasopharyngeal aspirate samples, IVIG; intravenous immunoglobulin, rhTM; recombinant human thrombomodulin, SIMV; synchronized intermittent mandatory ventilation, VTPC; volume target pressure control ventilation, Spont-PS; spontaneous pressure support ventilation 
Table 1. Changes in laboratory data of case 1 .

\begin{tabular}{|c|c|c|c|c|c|c|c|c|c|c|c|}
\hline & \multicolumn{11}{|c|}{ PICU } \\
\hline & Admission & & & & & & & & & & Discharge \\
\hline $\begin{array}{l}\text { The day 1st } \\
=\text { onset day }\end{array}$ & 7th & 8 th & 9th & 10th & 11 th & 12 th & 13th & 14th & 15 th & 16th & 17 th \\
\hline $\mathrm{CRP}(\mathrm{mg} / \mathrm{dL})$ & 18.1 & & & & 11.7 & 10 & 4.9 & & 2.2 & 1.5 & 0.8 \\
\hline WBC $(/ \mu \mathrm{l})$ & 28000 & & & & 19000 & 19000 & 14200 & 19900 & 11060 & 17800 & 12430 \\
\hline Plt $(x 1,000 / \mu 1)$ & 271 & 173 & 55 & 16 & 42 & 41 & 33 & 49 & 45 & 61 & 89 \\
\hline $\operatorname{AST}(\mathrm{U} / \mathrm{L})$ & 875 & & & & 65 & 54 & 62 & & 50 & 46 & 49 \\
\hline ALT (U/L) & 325 & & & & 106 & 93 & 49 & & 39 & 32 & 27 \\
\hline Cre $(\mu \mathrm{mol} / \mathrm{L})$ & 24 & & & & 35 & 64 & 47 & & 52 & 55 & 36 \\
\hline BUN (mg/dL) & 14.1 & & & & 7.4 & 16.5 & 14.6 & & 23.6 & 27 & 13.6 \\
\hline Fibrinogen $(\mathrm{g} / \mathrm{L})$ & 4.71 & 3.1 & 4.83 & 6 & 3.92 & 4.78 & 4.57 & 1.37 & 4.15 & 2.38 & 1.37 \\
\hline D-dimer(ng/mL) & & 1093 & 1014 & 1184 & 1252 & 1194 & 6791 & 1234 & 1193 & 897 & 834 \\
\hline PT (sec.) & 16.1 & 21.1 & 19.7 & 21.4 & 19.4 & 18.5 & 18.5 & 17.8 & 17 & 17.6 & 17.8 \\
\hline
\end{tabular}

on the day 8th, he was admitted to an emergency department of our hospital on the day 9th. He had past history of recurrent pneumonia three times for 3 months. Physical examination on admission to emergency department showed an infant with weight of $5.0 \mathrm{~kg}$; length of $52 \mathrm{~cm}$; body temperature of $39.0^{\circ} \mathrm{C}$; blood pressure of $54 / 34 \mathrm{mmHg}$; $\mathrm{HR}$ of 177 beats/min; and $\mathrm{SpO}_{2}$ of $85 \%$ in room air. PRISM III score was 9 . He was performed tracheal intubation quickly and sent to PICU, immediately. The arterial blood gas analysis in PICU showed $\mathrm{PaO}_{2}$ $69 \mathrm{mmHg}$ and $\mathrm{PaCO}_{2}, 115 \mathrm{mmHg}$ under the mechanical ventilation with $\mathrm{FiO}_{2} 1.0$, consequently $\mathrm{P} / \mathrm{F}$ ratio was $69 \mathrm{mmHg}$. His chest $\mathrm{X}$-ray showed bilateral infiltration without findings of heart failure (Figure 3). Laboratory findings were as follows, WBC count 24,000 cells/ $\mu \mathrm{l} ; \mathrm{RBC}$ count $330 \times 10^{4}$ cells/ $\mu$; PLT count $445 \times 10^{3}$ cells/ $\mu$; AST $361 \mathrm{U} / \mathrm{L}$; ALT $149 \mathrm{U} / \mathrm{L}$; BUN 10.4mg/dL; creatinine $56 \mu \mathrm{mol} / \mathrm{L}$; CRP $0.3 \mathrm{mg} /$ $\mathrm{dL}$; fibrinogen $1.79 \mathrm{~g} / \mathrm{L}$; and PT 17.9 seconds. No bacteria and fungi were detected in blood neither by culture nor by SeptiFast. Genomes of CMV $\left(8.6 \times 10^{6} / \mathrm{ml}\right)$ and pneumocystis jirovecii were detected in TLF by real time PCR assay. Adenovirus, Human rhinovirus, Mycobacterium tuberculosis were negative. He was suspected of CMV disease and Pneumocystis pneumonia (PCP). Administration of $10 \mathrm{mg} / \mathrm{kg} /$ day of ganciclovir and $480 \mathrm{mg}$ /days of S-T combination (SulfamethoxazoleTrimethoprim, SMX/TMP) were started. For prevention of secondary bacterial infection, administration of IIPM/CS and LVFX was initiated. Human immunodeficiency virus (HIV)-IgG was detected in plasma by ELISA and HIV-RNA was detected in plasma on the day 13th. CD4positive T cell number was $1640 / \mu \mathrm{l}$ on the day 10 th and $847 / \mu \mathrm{l}$ on the day 28th. He was treated as severe ARDS/sepsis developed from CMV disease and PCP with HIV infection.

On the next day of PICU admission (the day 10th), ISTH DIC

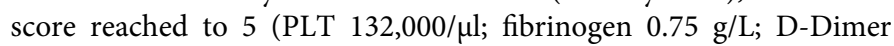
$4840 \mathrm{ng} / \mathrm{mL}$; PT 23.3 seconds), presenting a complication of DIC and administration of $380 \mathrm{U} / \mathrm{kg} /$ day of rhTM was started on the same day. In addition, to control of inflammation, $1 \mathrm{mg} / \mathrm{kg}$ of immunoglobulin was administrated intravenously for 2 days. The P/F ratio were improving gradually and he was extubated on the day 15 th. DIC score and laboratory data of AST/ALT also had been improved during the stay in PICU (Figure 4, Table 2). He had recovered from severe ARDS with sepsis/DIC successfully and moved from PICU to AIDS control center (ACC) for the treatment of anti-retroviral treatment on the day $16^{\text {th }}$ and discharged on the day $42^{\text {th }}$.

\section{Discussion}

We reported 2 Vietnamese infants under 3-month-old with

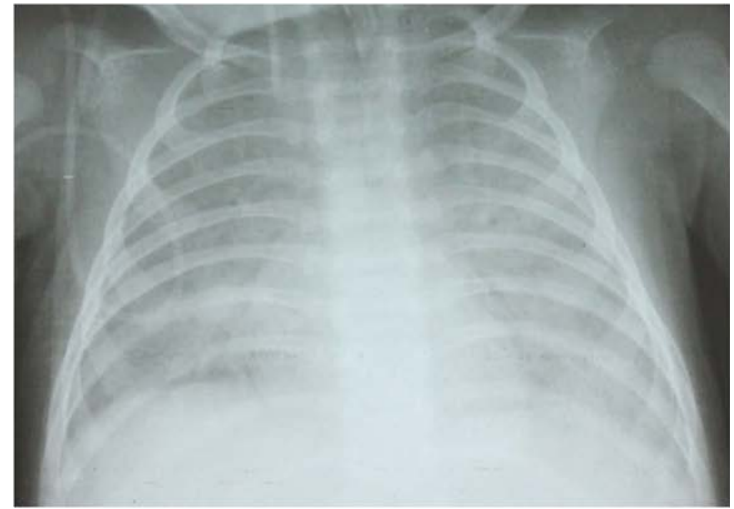

Figure 3. Chest X-ray on admission to PICU in Case 2.

severe ARDS/sepsis with DIC, which was developed from RSV pneumonia and PCP, respectively. The infant in Case 2 was infected with HIV and was suspected of immune dysfunction. Severe ARDS is generally thought as one of the most lethal conditions of the diseases in pediatric intensive care field. In our hospital, a PICU-mortality in patients with severe ARDS/sepsis has been more than $50 \%$. Therefore, the prognosis of these 2 infants were thought to be very severe on admission. We did a combination therapy including a lung protective support by a ventilator, medication of antibiotics and antiviral drugs for pulmonary sepsis, high-dose IVIG therapy to control inflammation, and administration of rhTM for anti-DIC. Both cases were the first cases that rhTM had been administered to Vietnamese infant in Vietnam. RhTM is a new anticoagulant agent that has both anti-coagulatory and anti-inflammatory effects and was introduced clinically on April 2008 in Japan [6]. Recently it is suggested that rhTM improved not only mortality in patients with sepsis-induced DIC but also respiratory dysfunction in patients with severe sepsis resulting the marked improvement of lung injury scores after administration of rhTM [17,18]. We administered rhTM according to the standard formula of rhTM (380 U/kg/days, 6days) and succeeded to improve both DIC score and P/F ratio (Figures 2 and 4). It was unknown how much the rhTM administaration contributed to the improvement of $\mathrm{P} / \mathrm{F}$ ratio in the presented cases.

We examined plasma levels of thrombomodulin, protein C activity, high mobility group box 1 (HMGB-1), and soluble receptor for advanced glycan endproducts (sRAGE) before and after rhTM administration. The rhTM is thrombomodulin-alfa and its pharmaceutical action in the human body is same as thrombomodulin 


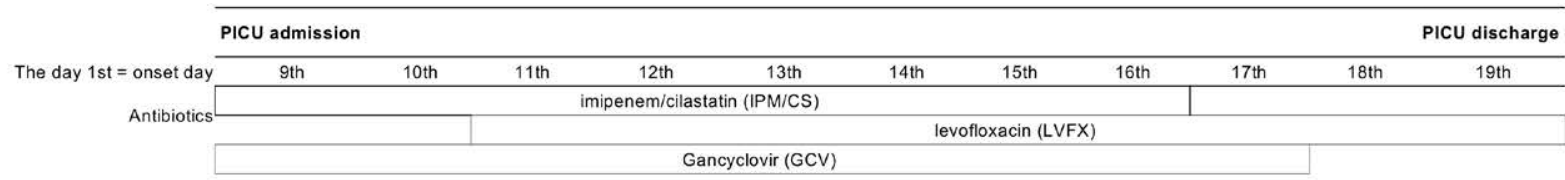

\begin{tabular}{|c|c|c|c|c|c|c|c|}
\hline \multirow{2}{*}{$\begin{array}{r}\text { PCR study (TLF/NPA) } \\
\text { IVIG }\end{array}$} & \multirow[t]{2}{*}{$\mathrm{CMV}$} & \multicolumn{6}{|c|}{ HIV } \\
\hline & & $\downarrow$ & $\downarrow$ & & & & \\
\hline rhTM & & $\downarrow$ & $\downarrow$ & $\downarrow$ & $\downarrow$ & $\downarrow$ & $\downarrow$ \\
\hline & ntubation & & & & & & extubation \\
\hline Ventilation & SIMV & $\mathrm{HFO}$ & & & & SIMV & Spont-PS \\
\hline
\end{tabular}

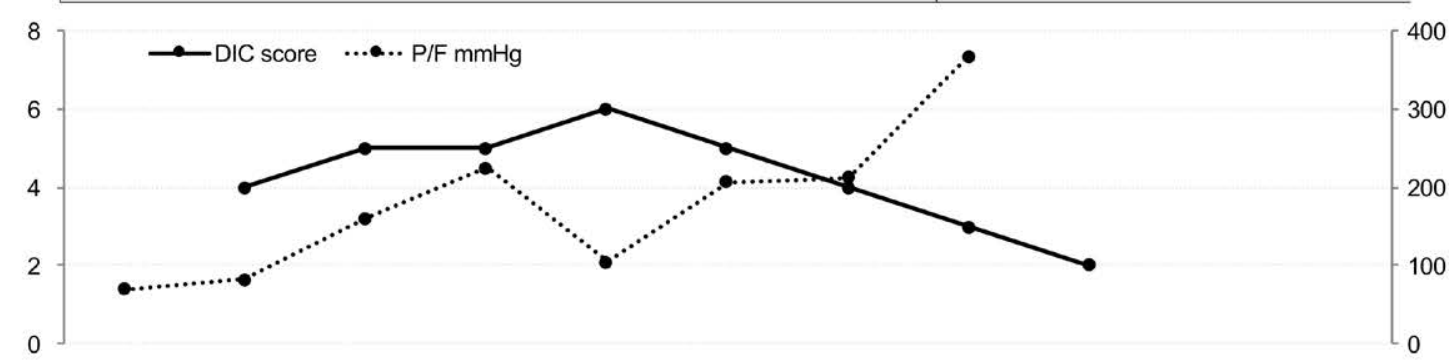

\begin{tabular}{|c|c|c|c|c|c|c|c|c|c|}
\hline \multirow{2}{*}{$\begin{array}{r}\mathrm{P} / \mathrm{F} \mathrm{mmHg} \\
\mathrm{DIC} \text { score }\end{array}$} & \multirow[t]{2}{*}{69} & 82 & 160 & 225 & 104 & 207 & 212 & \multicolumn{2}{|l|}{367} \\
\hline & & 4 & 5 & 5 & 6 & 5 & 4 & 3 & 2 \\
\hline HMGB1 (ng/ml) & & 29.8 & 36.6 & 29.1 & 22.7 & 18.4 & 18.9 & & \\
\hline RAGE $(p g / m l)$ & & 1904.5 & 337.5 & 317.2 & 320.2 & 250.2 & 253.3 & & \\
\hline proteinC activity (\%) & & & 25 & 30 & 32 & 34 & & & \\
\hline
\end{tabular}

Figure 4. Clinical course in Case 2. CMV; cytomegalovirus, HIV; human immunodeficiency virus, TLF/NPA; tracheal lavage fluid and/or nasopharyngeal aspirate samples, IVIG; intravenous immunoglobulin, rhTM; recombinant human thrombomodulin, SIMV; synchronized intermittent mandatory ventilation, HFO; high frequency oscillation ventilation, Spont-PS; spontaneous pressure support ventilation.

Table 2. Changes in laboratory data of case 2 .

\begin{tabular}{|c|c|c|c|c|c|c|c|c|}
\hline \multirow[b]{3}{*}{$\begin{array}{l}\text { The day 1st } \\
=\text { onset day }\end{array}$} & \multicolumn{8}{|c|}{ PICU } \\
\hline & \multicolumn{7}{|l|}{ Admission } & \multirow{2}{*}{$\begin{array}{l}\text { Discharge } \\
16 \text { th }\end{array}$} \\
\hline & 9th & 10th & 11th & 12th & 13th & 14th & 15th & \\
\hline $\mathrm{CRP}(\mathrm{mg} / \mathrm{dL})$ & 0.3 & & 0.32 & 0.94 & 1.2 & & 1.2 & \\
\hline WBC $(/ \mu \mathrm{l})$ & 24000 & 13000 & 8800 & 5200 & 5600 & 5900 & 8300 & 6700 \\
\hline Plt $(\mathrm{x} 1,000 / \mu \mathrm{l})$ & 445 & 132 & 128 & 67 & 53 & 50 & 61 & 80 \\
\hline $\operatorname{AST}(\mathrm{U} / \mathrm{L})$ & 361 & 1757 & 984 & 413 & 244 & 153 & 113 & 102 \\
\hline ALT (U/L) & 149 & 874 & 726 & 445 & 274 & 189 & 137 & 83 \\
\hline Cre $(\mu \mathrm{mol} / \mathrm{L})$ & 56 & 48 & 49 & 57 & 53 & 61 & 61 & 46 \\
\hline BUN (mg/dL) & 10.4 & 7.5 & 8.4 & 15.9 & 16.5 & 17.4 & 15.9 & 12 \\
\hline Fibrinogen $(\mathrm{g} / \mathrm{L})$ & 1.79 & 0.75 & 2.16 & 1.8 & 2 & 2.76 & 3 & \\
\hline D-dimer $(\mathrm{ng} / \mathrm{mL})$ & 1029 & 4840 & 3190 & 4437 & 3811 & 1070 & 733 & \\
\hline PT (sec.) & 17.9 & 23.3 & 17.2 & 17.7 & 13.1 & 13 & 12.2 & \\
\hline
\end{tabular}

[6]. The levels of thronbomodulin increased after rhTM administration and kept high concentration during rhTM therapy (data not shown). It is discussed that thombomodulin activates protein $\mathrm{C}$ and activated protein $C$ had anti-inflammatory property [19]. In fact, protein $C$ activity in Case 1 and Case 2 increases from $10 \%$ to $30 \%$ and $25 \%$ to $34 \%$, respectively, before and after rTM administration. This suggested the efficacy of rhTM to increase protein C activity. HMGB1 has been reported to be one of the late mediators and one of the damageassociated molecular patterns (DAMPS) associated with innate immunity [20-22]. Thrombomodulin binds to HMGB-1, aids the proteolytic cleavage of HMGB1 by thrombin, and degrades HMGB-1 [23]. The plasma levels of HMGB1 was high before administration of rhTM, and it started to decrease a few days later than the administration start date (Figures 2 and 4). Increased levels of HMGB1 and sRAGE are reported to be associated with lung inflammations [24]. RAGE is reported to be a marker of Type I alveolar epithelial cell injury and plasma levels of sRAGE is significantly higher in patients with acute lung injury than healthy volunteers [25]. Though the plasma levels of sRAGE were high before rhTM administration in both cases (1802 pg/ $\mathrm{ml}$ in Case 1 and $1905 \mathrm{pg} / \mathrm{ml}$ in Case 2, normal: $170 \mathrm{pg} / \mathrm{ml}$ ), after rhTM administration, the levels of sRAGE decreased rapidly (Figures 2 and 4). This was not efficacy by IVIG but by rhTM, because IVIG and rhTM were administered on different day in Case 1.

The mechanism of medicinal action of rhTM to improve the pulmonary edema and respiratory dysfunction in severe ARDS have not yet elucidated. However, rhTM administration to the patients with severe ARDS/sepsis with DIC is worth to be considered as a combined therapy expecting not only anti- DIC, but also improvement of respiratory dysfunction.

\section{Conclusion}

We showed here successful treatment of pneumonia-induced severe ARDS complicated with DIC in two infants using recombinant 
human thrombomodulin. Both of them were successfully survived from severe ARDS/sepsis with DIC, and discharged from hospital. RhTM administration is worth to be considered as a combined therapy for severe ARDS/sepsis with DIC.

\section{Acknowledgements}

Our research was supported by the Research Program on Emerging and Re-Emerging Infectious Diseases from the Agency for Medical Research and Development, Japan.

\section{Conflict of interests}

The authors state that they have no conflict of interest.

\section{Ethical considerations}

This study was approved by the biomedical research ethics committee of National Hospital of Pediatrics Research Institute for Child Health (NHP-RICH, Hanoi, Vietnam) (reference number: NHPRICH-15-008) and ethical committee of National Center for Global Health and Medicine (NCGM, Tokyo, Japan) (reference number: NCGM-G-001853-00) and written informed concent was obtained from the parents according to the study protocol.

\section{References}

1. Madhi SA, De Wals P, Grijalva CG, Grimwood K, Grossman R, et al. (2013) The burden of childhood pneumonia in the developed world: a review of the literature. Pediatr Infect Dis J 32: e119-27. [Crossref]

2. Dahlem P, van Aalderen WM, Bos AP (2007) Pediatric acute lung injury. Paediatr Respir Rev 8: 348-362.

3. Randolph AG (2009) Management of acute lung injury and acute respiratory distress syndrome in children. Crit Care Med 37: 2448-2454. [Crossref]

4. Rubenfeld GD, Caldwell E, Peabody E Weaver J, Martin DP, et al. (2005) Incidence and outcomes of acute lung injury. N Engl J Med 353: 1685-1693. [Crossref]

5. Perl M, Lomas-Neira J, Venet F, Chung CS, Ayala A (2011) Pathogenesis of indirect (secondary) acute lung injury. Expert Rev Respir Med 5: 115-126. [Crossref]

6. Saito H, Maruyama S, Shimazaki S, Yamamoto Y, Aikawa N, et al. (2007) Efficacy and safety of recombinant human soluble thrombomodulin (ART-123) in disseminated intravascular coagulation: results of a phase III, randomized, double-blind clinical trial. J Thromb Haemost 5: 31-41. [Crossref]

7. Shirahata A, Mimuro J, Takahashi H, Kitajima I, Tsuji H, et al. (2014) Recombinant soluble human thrombomodulin (thrombomodulin alfa) in the treatment of neonatal disseminated intravascular coagulation. Eur J Pediatr 173: 303-311. [Crossref]

8. Shirahata A, Mimuro J, Takahashi H, Tsuji H, Kitajima I, et al. (2014) Postmarketing Surveillance of Recombinant Human Soluble Thrombomodulin (Thrombomodulin $\alpha$ ) in Pediatric Patients With Disseminated Intravascular Coagulation. Clin Appl Thromb Hemost 20: 465-472. [Crossref]

9. Ogawa Y, Yamakawa K, Ogura H, Kiguchi T, Mohri T, et al. (2012) Recombinant human soluble thrombomodulin improves mortality and respiratory dysfunction in patients with severe sepsis. J Trauma Acute Care Surg 72: 1150-1157. [Crossref]
10. Tsushima K, Yokoyama T, Koizumi T, Kubo K, Tatsumi K (2013) The concept study of recombinant human soluble thrombomodulin in patients with acute respiratory distress syndrome. Int J Clin Med 4: 488-495.

11. The ARDS Definition Task Force (2012) Acute Respiratory Distress Syndrome, The Berlin Definition. JAMA 307: 2526-2533. [Crossref]

12. The ACCP/SCCM Consensus conference committee (1992) Definitions for sepsis and organ failure and guidelines for the use of innovate therapies in sepsis. Chest 101: 1644-1655. [Crossref]

13. Pollack MM, Patel KM, Ruttimann UE (1997) The Pediatric Risk of Mortality III-Acute Physiology Score (PRISM III-APS): a method of assessing physiologic instability for pediatric intensive care unit patients. J Pediatr 131: 575-581. [Crossref]

14. Suberviola B, Márquez-López A, Castellanos-Ortega A, Fernández-Mazarrasa C, Santibáñez M, et al. (2016) Microbiological Diagnosis of Sepsis: Polymerase Chain Reaction System versus Blood Cultures. Am J Crit Care 25: 68-75. [Crossref]

15. Pediatric Acute Lung Injury Consensus Conference Group (2015) Pediatric acute respiratory distress syndrome: consensus recommendations from the Pediatric Acute Lung Injury Consensus Conference. Pediatr Crit Care Med 16: 428-439.

16. Taylor FB Jr, Toh CH, Hoots WK, Wada H, Levi M (2001) Scientific Subcommittee on Disseminated Intravascular Coagulation (DIC) of the International Society on Thrombosis and Haemostasis (ISTH). Towards definition, clinical and laboratory criteria, and a scoring system for disseminated intravascular coagulation. Thromb Haemost 86: 1327-1330.

17. Yamakawa K, Ogura H, Fujimi S, Morikawa M, Ogawa Y, et al. (2013) Recombinant human soluble thrombomodulin in sepsis-induced disseminsted intravascular coagulation: a multicenter propensity score analysis. Intensive care Med 39: 644-652. [Crossref]

18. Yamakawa K, Aihara M, Ogura H, Yuhara H, Hamasaki T, et al. (2015) Recombinan human soluble thrombomodulin in severe sepsis: a systematic review and metaanalysis. J Thromb Haemost 4: 508-519. [Crossref]

19. Okamoto T, Tanigami H, Suzuki K, Shimaoka M (2012) Thrombomodulin: A Bifunctional Modulator of Inflammation and Coagulation in Sepsis. Crit Care Res Pract: 614545.

20. Wang H, Bloom O, Zhang M, Vishnubhakat JM, Ombrellino M, et al. (1999) HMG-1 as a late mediator of endotoxin lethality in mice. Science 285: 248-251. [Crossref]

21. Foell D, Wittkowski H, Roth J (2007) Mechanisms of Disease: a 'DAMP' view of inflammatory arthritis. Nat Clin Pract Rheumatol. 3: 382-390. [Crossref]

22. Abraham E, Arcaroli J, Carmody A, Wang H, Tracey KJ (2000) HMG-1 as a mediator of acute lung inflammation. J Immunol 165: 2950-2954. [Crossref]

23. Ito T, Kawahara K, Okamoto K, Yamada S, Yasuda M, et al. (2008) Proteolytic cleavage of high mobility group box 1 protein by thrombin-thrombomodulin complexes. Arterioscler Thromb Vasc Biol 28: 1825-1830. [Crossref]

24. Nakamura T, Sato E, Fujiwara N, Kawagoe Y, Maeda S, et al. (2011) Increased levels of soluble receptor for advanced glycation end products (sRAGE) and high mobility group box 1 (HMGB1) are associated with death in patients with acute respiratory distress syndrome. Clin Biochem 44: 601-604. [Crossref]

25. Mauri T, Masson S, Pradella A, Bellani G, Coppadoro A, et al. (2010) Elevated plasma and alveolar levels of soluble receptor for advanced glycation endproducts are associated with severity of lung dysfunction in ARDS patients. Tohoku J Exp Med 222 105-112. [Crossref]

Copyright: (C2017 Phuc PH. This is an open-access article distributed under the terms of the Creative Commons Attribution License, which permits unrestricted use, distribution, and reproduction in any medium, provided the original author and source are credited. 